\title{
Quantitative observations on iliac bone marrow mast cells in chronic renal failure
}

\author{
KATHLEEN M. PEART AND H. A. ELLIS \\ From the Department of Pathology, University of Newcastle upon Tyne
}

SYNOPSIS Mast cells have been counted in sections of iliac bone from 61 control subjects at necropsy. Mast cells were found in all but three, and the range was $0-33 \cdot 7$, median 1.95 per $\mathrm{mm}^{2}$ marrow. The majority $(82 \%)$ had $<4.99$ mast cells per $\mathrm{mm}^{2}$ marrow; in $37.7 \%$ there was $<1$ mast cell per $\mathrm{mm}^{2}$ marrow.

In a group of 45 patients with chronic renal failure there was a significant increase in the numbers of mast cells $(P<0.001)$ with a range of $0.96-55.63$, median 9.55 per $\mathrm{mm}^{2}$ marrow. Mast cells were common in the areas of marrow fibrosis associated with osteitis fibrosa but this was not the sole cause of the increase since there was also an excess of mast cells in the non-fibrous parts of the marrow. There was a tendency towards greater numbers of mast cells in those cases with most marked osteitis fibrosa in association with the prominent marrow fibrosis, but there was no significant relationship between mast cell numbers and other features of oesteitis fibrosa such as the number of osteoclasts and the amount of woven bone formation. There was no relationship between the numbers of mast cells and the amounts of total bone, osteoid, percentage mineralization of cancellous bone, or the presence of osteomalacia.

Shortly after we began a long-term study of the histopathology of azotaemic renal osteodystrophy some eight years ago one of us observed an apparent increase in the number of marrow mast cells in toluidine blue stained sections of iliac bone from patients with chronic azotaemia. More recently, Neiman et al (1972), in a letter to the Lancet, referred briefly to their finding of increased numbers of mast cells in the spleen and bone marrow of patients with uraemia.

There is little quantitative information in the literature concerning marrow mast cells in man. In the past, the finding of such cells has been regarded as abnormal (Fadem, 1951) and it is now recognized that mast cells are present in normal bone marrow (Johnstone, 1954; Selye, 1965). The purpose of the present paper is to report quantitative observations on the mast cells in histological sections of iliac bone marrow in $\mathbf{4 5}$ patients with chronic renal failure. For comparison samples of iliac bone were obtained at necropsy from 61 cases of sudden death. Numbers of marrow mast cells have been considered in relation to the severity of osteitis fibrosa, the presence of

Received for publication 26 June 1975. excess osteoid, and osteomalacia, all of which are features of azotaemic renal osteodystrophy.

\section{Material and Methods}

BONE

Samples of iliac bone were examined from 45 patients with chronic renal failure due to a variety of renal disorders. Iliac bone was obtained by transilial trephine bone biopsy in 22 patients and at necropsy in 23. Of the patients coming to necropsy, 11 had terminal peritoneal dialysis, one had a terminal haemodialysis, and two had been treated by peritoneal dialysis for two months. The biopsy patients were near end stage renal failure. Three had been treated by peritoneal dialysis for two to three months, and 12 required dialysis after periods varying from a few days up to three months after bone biopsy.

Control iliac bone samples were obtained at necropsy from 61 previously physically healthy individuals after sudden death due to a variety of causes such as trauma and poisoning.

Blocks of iliac bone were fixed in neutral $10 \%$ formalin, decalcified in formic acid, and double embedded using low viscosity nitrocellulose; $5 \mu$ 
sections were stained by $0.05 \%$ toluidine blue solution at $\mathbf{p H} 3 \cdot 8$.

MAST CELLS IN MARROW AND FIBROUS

TISSUE

We have regarded as marrow tissue mast cells any connective tissue cell possessing cytoplasmic granules that stain metachromatically. Basophils possess similar granules but differ morphologically from mast cells in that they are generally smaller and have a lobulated nucleus. Since human basophilic granules are water soluble, metachromasia is lost after aqueous fixation, and basophils are not liable to be confused with mast cells in histological sections.

Mast cells were counted in the marrow of cancellous bone in a square measuring $0.5 \times 0.5 \mathrm{~cm}$ marked out on the cover slip in an area immediately beneath the iliac crest in the case of the necropsy samples and in the middle of the biopsy specimens, using $\times 40$ objective and $\times 10$ eyepiece incorporating a squared graticule. The proportion of total bone within the measured area was determined using a point-counting technique (Ellis and Peart, 1972) and the number of mast cells per $\mathrm{mm}^{2}$ of marrow was then calculated. In 24 of the patients with renal failure the amount of marrow fibrous tissue resulting from osteitis fibrosa was also measured using a point-counting technique (Ellis and Peart, 1973). In these patients, mast cells were counted separately in fibrous tissue and in mixed fatty and cellular marrow to ascertain whether or not mast cells were concentrated in the fibrous tissue.

\section{OSTEITIS FIBROSA, EXCESS OSTEOID, AND OSTEOMALACIA}

The severity of osteitis fibrosa was assessed semiquantitatively on a scale of grades from 0 to 5 , and the number of osteoclasts and amount of woven bone were determined as previously described (Ellis and Peart, 1973). The amount of osteoid, expressed as a percentage of the measured area, and the percentage mineralization of cancellous bone were determined by a point-counting technique using undecalcified sections (Ellis and Peart, 1972). Osteomalacia was diagnosed on the basis of the presence of an excess of osteoid with abnormally wide osteoid seams and a reduced or absent calcification front (Ellis and Peart, 1973; Ellis, 1973).

\section{Results}

\section{CONTROL SUBJECTS}

The arithmetic mean number of marrow mast cells for the $\mathbf{3 8}$ males and $\mathbf{2 3}$ females, varying in age from 5 to 93 years, was 3.93 per $\mathrm{mm}^{2}$ with a median of 1.95 per $\mathrm{mm}^{2}$. There was no significant difference
$(P>0.10)$ between the means for males (4.70 per $\stackrel{0}{=}$ $\mathrm{mm}^{2}$ ) and females (2.65 per $\left.\mathrm{mm}^{2}\right)$. Plotting the 음 distribution of mast cell values in relation to age revealed no significant relationship in males or $\stackrel{\text { ? }}{+}$ females. As the figure shows, there was considerable므 variation in the number of marrow mast cells $\frac{\bar{\sigma}}{\overline{0}}$ between individuals, and the distribution is not $\frac{\bar{D}}{D}$ normal. Mast cells were found in all but three of the $\stackrel{\mathbb{Q}}{\varrho}$ 61 samples examined. The highest value (33.76 per $\mathrm{mm}^{2}$ ) was in an 11-year old boy and this in the area $\overrightarrow{0}$ immediately contiguous with the zone of endochondral ossification beneath the iliac crest. A second $\vec{\omega}$ count at a distance of $1.0 \mathrm{~cm}$ below this gave a lower value of 4.67 mast cells per $\mathrm{mm}^{2}$. In three older용 individuals aged 21 to 22 years, duplicate counts ${ }_{\infty}$ made at distances of $0.5 \mathrm{~cm}$ and $1.5 \mathrm{~cm}$ below the $\vec{N}$ crest revealed less marked differences, the paired

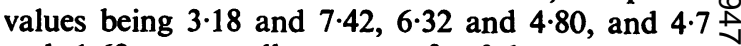
and 1.68 mast cells per $\mathrm{mm}^{2}$ of bone marrow, 음 respectively.

The majority $(82 \%)$ of the control subjects had $\vec{\nabla}$ mast cell values within the range 0 to 4.99 per $\mathrm{mm}^{2}$, and in $37.7 \%$ of individuals there was $<1$ mast cell per $\mathrm{mm}^{2}$. The six individuals $(10 \%)$ with $>10$ mast cells per $\mathrm{mm}^{2}$ were males aged 11 to 47 years. The mode of death was unrelated to the higher valueg $\vec{v}$ Thus one died from asphyxia trapped in a disused or pit, one from multiple injuries, and the others from various poisons including carbon monoxide, barbitit

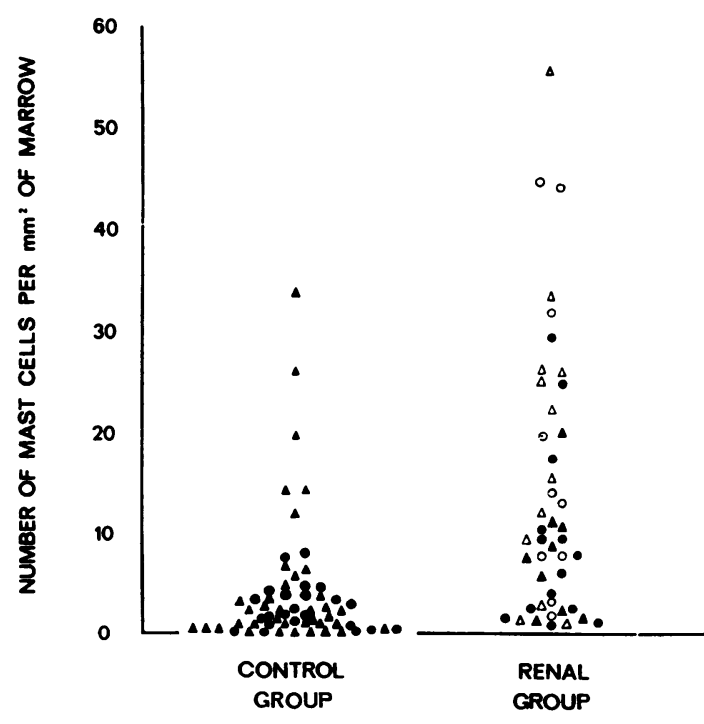

Figure Distribution of the numbers of iliac bone marrow mast cells in 61 control subjects and in 45 patients with chronic renal failure $\triangle \Delta$ and $\Delta$ males, biopsy and necropsy samples; $\bigcirc$ and females, biopsy and necropsy samples. 
rates, and aspirin. Other subjects dying from these poisons had much lower values. Thus four with carbon monoxide poisoning had 0 to 0.52 mast cells per $\mathrm{mm}^{2}$. In addition, in a selected group of previously healthy individuals comprising 25 males and 12 females in whom death had been almost instantaneous and predominantly the result of trauma such as road accidents, the mean values for males and females were 3.81 and 2.21 mast cells per $\mathrm{mm}^{2}$, respectively, and these did not differ significantly from those obtained for the control group as a whole.
CHRONIC RENAL FAILURE

Total marrow mast cells

The results of mast cell counts in the iliac bone marrow of the 45 patients with chronic renal failure are summarized in the figure and given in more detail in table I. The values in the figure refer to the numbers of mast cells in the whole marrow, including those in mixed fatty and cellular areas and in any fibrous areas resulting from osteitis fibrosa. Although there is some overlap with values obtained in the control group, in general values were higher and the arithmetic mean was 13.75 per $\mathrm{mm}^{2}$ with a median of

\begin{tabular}{|c|c|c|c|c|c|c|c|c|c|c|}
\hline \multirow{2}{*}{\multicolumn{2}{|c|}{$\begin{array}{l}\text { Case No. Age } \\
\text { and Sex }\end{array}$}} & \multicolumn{2}{|c|}{ Mast Cells per $\mathrm{mm}^{2}$} & \multicolumn{3}{|c|}{ Mineralization Data } & \multicolumn{4}{|c|}{ Osteitis Fibrosa Data } \\
\hline & & \multirow{2}{*}{$\begin{array}{l}\text { All Marrow } \\
9.52\end{array}$} & \multirow{2}{*}{$\begin{array}{l}\text { Non-Fibrous } \\
\text { Marrow }\end{array}$} & \multirow{2}{*}{$\begin{array}{l} \\
2 \cdot 57\end{array}$} & \multirow{2}{*}{$\frac{M}{90.5}$} & \multirow{2}{*}{$\frac{O M}{+}$} & \multirow{2}{*}{$\frac{O C L}{0.22}$} & \multirow{2}{*}{$\begin{array}{c}W B \\
-\end{array}$} & \multirow{2}{*}{$\begin{array}{r}M F \\
8 \cdot 6\end{array}$} & \multirow{2}{*}{$\begin{array}{c}\text { OFG } \\
3\end{array}$} \\
\hline 1 & $15 \mathrm{M}$ & & & & & & & & & \\
\hline 2 & $16 F$ & $44 \cdot 74$ & 2.63 & 0.72 & 98.4 & - & 5.63 & - & $14 \cdot 1$ & 4 \\
\hline 3 & $24 F$ & 31.89 & $29 \cdot 52$ & 0.09 & $99 \cdot 6$ & - & 0.71 & - & 1.4 & 2 \\
\hline 4 & $25 \mathrm{M}$ & $33 \cdot 29$ & 32.91 & $0 \cdot 15$ & $99 \cdot 3$ & - & $0 \cdot 24$ & - & 0.5 & $1 \cdot 5$ \\
\hline 5 & $27 F$ & $14 \cdot 23$ & 11.69 & 0.39 & $97 \cdot 5$ & - & 0.56 & - & $2 \cdot 5$ & 2 \\
\hline 6 & $29 M$ & 2.89 & 2.62 & 0.28 & 98.9 & - & 0.79 & - & 0.9 & 2 \\
\hline 7 & $31 \mathrm{M}$ & $22 \cdot 37$ & $8 \cdot 21$ & $4 \cdot 02$ & $88 \cdot 5$ & + & 1.55 & - & $6 \cdot 5$ & 3 \\
\hline 8 & $32 \mathrm{M} \mathrm{(2)}$ & $1 \cdot 18$ & 0.93 & 0.57 & 98.0 & - & 0.38 & 6.8 & 0.4 & 1.5 \\
\hline 9 & $33 \mathrm{~F}$ & $19 \cdot 98$ & 18.06 & 6.44 & $80 \cdot 8$ & + & 1.49 & - & $3 \cdot 3$ & 3 \\
\hline 10 & $40 \mathrm{M}(17)$ & $26 \cdot 37$ & $26 \cdot 36$ & 0.31 & $98 \cdot 7$ & - & 0.96 & $5 \cdot 3$ & 0.7 & 2 \\
\hline 11 & $42 F$ & 1.86 & 1.46 & 0.04 & 99.9 & - & 0.27 & - & 0.5 & 2 \\
\hline 12 & $45 F(6)$ & $7 \cdot 87$ & 6.03 & 3.94 & $82 \cdot 2$ & + & $7 \cdot 70$ & 50.8 & $8 \cdot 0$ & 4 \\
\hline 13 & $45 \mathrm{M}$ & 26.02 & $7 \cdot 21$ & 0.49 & $98 \cdot 1$ & - & 2.67 & - & $13 \cdot 1$ & 4 \\
\hline 14 & $45 \mathrm{M}$ & $1 \cdot 32$ & $1 \cdot 32$ & 0.18 & $99 \cdot 3$ & - & $0 \cdot 20$ & - & 0 & 1 \\
\hline 15 & $47 F$ & 44.06 & 10.95 & 1.05 & 95.6 & - & $1 \cdot 31$ & - & $4 \cdot 8$ & 3.5 \\
\hline 16 & $48 \mathrm{~F}$ & $3 \cdot 25$ & 2.82 & 0.11 & $99 \cdot 3$ & - & 0.28 & - & 1.0 & 1 \\
\hline 17 & $49 M(18)$ & 25.03 & $21 \cdot 70$ & 1.00 & 95.0 & - & $5 \cdot 00$ & $61 \cdot 6$ & $5 \cdot 7$ & 3.5 \\
\hline 18 & $50 \mathrm{M}$ & $15 \cdot 51$ & 13.74 & $1 \cdot 51$ & $93 \cdot 9$ & - & $3 \cdot 15$ & - & $11 \cdot 5$ & 4 \\
\hline 19 & $52 \mathrm{M}$ & 55.63 & $43 \cdot 75$ & $1 \cdot 81$ & $92 \cdot 4$ & - & $9 \cdot 46$ & - & 10.4 & 4 \\
\hline 20 & $53 \mathrm{~F}$ & $7 \cdot 85$ & 2.61 & $1 \cdot 84$ & $91 \cdot 8$ & - & $1 \cdot 58$ & - & 3.6 & $2 \cdot 5$ \\
\hline 21 & $54 \mathrm{M}$ & $12 \cdot 10$ & 844 & 0.75 & $96 \cdot 2$ & - & 0.33 & - & 0.6 & 2 \\
\hline 22 & $58 \mathrm{~F}$ & 13.01 & $5 \cdot 75$ & 0.48 & $98 \cdot 2$ & - & $2 \cdot 16$ & - & 1.5 & 3 \\
\hline 23 & $23 F$ & $1 \cdot 21$ & - & $0 \cdot 10$ & $99 \cdot 5$ & - & 0.02 & $9 \cdot 6$ & 0.1 & 1 \\
\hline 24 & 27F (28) & 0.96 & - & $5 \cdot 35$ & 85.6 & + & $2 \cdot 49$ & $23 \cdot 3$ & $2 \cdot 0$ & $2 \cdot 5$ \\
\hline 25 & 29M (57) & $11 \cdot 26$ & 11.09 & 0.15 & 99.6 & - & 0.56 & $10 \cdot 1$ & 0.9 & 2 \\
\hline 26 & $35 F$ (15) & 2.62 & - & $2 \cdot 89$ & $92 \cdot 7$ & - & 1.62 & 36.9 & 1.6 & 3 \\
\hline 27 & $37 \mathrm{M}$ (24) & $10 \cdot 77$ & - & 0.08 & 99.6 & - & 0.30 & 0 & 0.2 & 2 \\
\hline 28 & $40 \mathrm{M}(3)$ & $20 \cdot 19$ & - & 0.04 & 99.8 & - & 0.74 & $7 \cdot 4$ & 0.7 & 2 \\
\hline 29 & $42 F(31)$ & $10 \cdot 49$ & $5 \cdot 47$ & 4.65 & $86 \cdot 6$ & + & $2 \cdot 64$ & $29 \cdot 9$ & $2 \cdot 1$ & 3 \\
\hline 30 & $42 \mathrm{M}(39)$ & $8 \cdot 88$ & - & 0.03 & 99.9 & - & 0.79 & $5 \cdot 1$ & 0.4 & 2 \\
\hline 31 & $43 M(48)$ & $2 \cdot 39$ & - & 0.01 & $100 \cdot 0$ & - & 0.59 & 3.0 & 1.0 & 2 \\
\hline 32 & $45 F(44)$ & $9 \cdot 77$ & - & 0.02 & 99.9 & - & 0.36 & $4 \cdot 3$ & 0.3 & 2 \\
\hline 33 & $45 F(5)$ & $17 \cdot 54$ & - & $6 \cdot 22$ & $79 \cdot 7$ & + & 0.67 & $33 \cdot 6$ & 0.6 & $2 \cdot 5$ \\
\hline 34 & $50 \mathrm{M}(45)$ & 1.62 & - & 0.03 & 99.9 & - & 0.06 & $2 \cdot 6$ & 0.1 & 1 \\
\hline 35 & $50 \mathrm{M}(32)$ & 5.89 & - & 0.02 & 99.9 & - & 0.48 & $21 \cdot 2$ & $1 \cdot 1$ & $2 \cdot 5$ \\
\hline 36 & $51 \mathrm{~F}(40)$ & 6.05 & - & 0.04 & 99.4 & - & $0 \cdot 27$ & 8.7 & 0.3 & 2 \\
\hline 37 & $53 M(41)$ & $7 \cdot 62$ & - & 0.59 & $98 \cdot 2$ & - & 0.36 & $9 \cdot 6$ & 0.7 & 2 \\
\hline 38 & $54 \mathrm{~F}$ (42) & $25 \cdot 05$ & - & $0 \cdot 18$ & $99 \cdot 1$ & - & 0.96 & $43 \cdot 7$ & $2 \cdot 6$ & 3 \\
\hline 39 & 55F (19) & $4 \cdot 04$ & - & $0 \cdot 12$ & $99 \cdot 2$ & - & 0.06 & 6.6 & 0 & 0 \\
\hline 40 & $58 F \quad(10)$ & $29 \cdot 51$ & - & 8.08 & 63.6 & + & 0.96 & 16.6 & $1 \cdot 4$ & 2 \\
\hline 41 & $59 F(43 b)$ & $1 \cdot 57$ & - & $0 \cdot 36$ & 98.4 & - & 0.59 & $23 \cdot 1$ & 1.0 & 2 \\
\hline 42 & 60F (11) & $9 \cdot 55$ & - & 0.04 & $99 \cdot 6$ & - & 0.66 & $8 \cdot 3$ & 0.4 & 2 \\
\hline 43 & $62 F(21 b)$ & $7 \cdot 98$ & - & $2 \cdot 64$ & 73.9 & + & $4 \cdot 40$ & $43 \cdot 8$ & $13 \cdot 8$ & $4 \cdot 5$ \\
\hline 44 & $68 \mathrm{M}(47)$ & $1 \cdot 39$ & - & $17 \cdot 16$ & 61.0 & + & 0.35 & $18 \cdot 3$ & 1.6 & 2 \\
\hline 45 & $70 F$ & $2 \cdot 56$ & - & 0.01 & $100 \cdot 0$ & - & 0.11 & 0 & $0 \cdot 1$ & 1 \\
\hline
\end{tabular}

Table I Details of the numbers of marrow mast cells, mineralization of bone, and severity of osteitis fibrosa in 45 patients with chronic renal failure

O, \% measured area comprising osteoid; $\mathbf{M}, \%$ mineralization of cancellous bone; OM, osteomalacia + or - ; OCL, number of osteoclasts per $\mathrm{mm}^{2}$ of cancellous bone and marrow; WB, woven bone $\%$ of cancellous bone trabeculae; MF, $\%$ measured area comprising fibrous tissue; OFG, osteitis fibrosa grade

Figures in brackets refer to the case numbers in a previous paper (Ellis and Peart, 1973). Present cases 1 to 22 biopsy bone samples : cases 23 to 45 necropsy bone samples. 
9.55 per $\mathrm{mm}^{2}$. Thus in only one individual $(2.2 \%)$ was there $<1.0$ mast cell per $\mathrm{mm}^{2}$ compared with a corresponding value of $37.7 \%$ in the control group. In contrast, the number of mast cells exceeded 5 per $\mathrm{mm}^{2}$ in $68.9 \%$ of patients with chronic renal failure compared with $18.0 \%$ of controls. Comparison of the control and renal groups by the Mann-Whitney test revealed a significantly higher mean number of marrow mast cells in patients with chronic renal failure (table II). This was true for renal patients whether the bone sample had been obtained by transilial biopsy or at necropsy. The biopsy series had significantly more marrow mast cells than did the necropsy series $(P<0.02)$.

\section{Mast cells and marrow fibrosis}

Mast cells in the marrow of patients with chronic renal failure occurred both in the mixed fatty and cellular areas and in the zones of marrow fibrosis constituting part of the repair reaction to osteitis fibrosa. Mast cells were commonly conspicuous within the cellular fibrous tissue occupying resorption lacunae and lying alongside cancellous trabeculae. In 24 patients with renal failure ( 22 bone biopsy and 2 necropsy samples) differential counts were made of the number of mast cells in the various components of the marrow. Very high values were found in the fibrous areas within the range 0 to 536.4 mast cells per $\mathrm{mm}^{2}$, arithmetic mean 148.8 and median 98.27 per $\mathrm{mm}^{2}$. When the number of total marrow mast cells was plotted against the percentage of marrow occupied by fibrous tissue there was a significant linear relationship $(P<0.001)$ with a correlation coefficient $(r)=0 \cdot 474$, although there was a fairly wide scatter of individual values about $\frac{\overrightarrow{0}}{\vec{\sigma}}$ the calculated regression line.

The large number of mast cells within the fibrous $\vec{\Rightarrow}$ parts of the marrow did not alone account for the increase in total marrow mast cells in the patients with chronic renal failure. Thus the differential $\frac{\bar{\sigma}}{\bar{D}}$ counts in 24 cases also revealed an increased number $\vec{\sigma}$ of mast cells in the mixed fatty and cellular compon- $\bigcirc$ ent of the marrow with from 0.93 to 43.75 mast cells क per $\mathrm{mm}^{2}$ (arithmetic mean 11.60 and median $7.71 \vec{\circ}$ per $\mathrm{mm}^{2}$ ), which was significantly higher than the number of mast cells found in the control marrows $\vec{\omega}$ $(\mathbf{P}<0.001)$.

Number of mast cells and severity of osteitis fibrosa That mast cells were common within the fibrous $\vec{N}$ component of the marrow suggested the possibility 0 that the increased number of mast cells in azotaemia might be the result of the osteitis fibrosa due to 을 secondary hyperparathyroidism. Since the osteitis fibrosa grades are non-parametric it was not possible

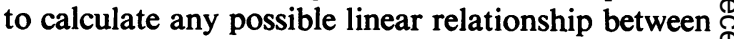
the number of marrow mast cells and the severity of $\frac{\mathbb{}}{3}$ the osteitis fibrosa. There was a wide range of mast $\underset{\Phi}{\mathbb{D}}$ cell numbers within each osteitis fibrosa grade, with a tendency towards most mast cells in the bons $\varphi$ showing the more severe grades of osteitis fibros? Comparison of the mean numbers of mast cells bone with osteitis fibrosa grades 0 to 2 and grades 2.5 to 5 showed more mast cells in the group with severe osteitis fibrosa (table III) when biopsy and necropsy specimens were taken together $(P<0.05)$. $\stackrel{\unrhd}{\unrhd}$ There were similar numbers of mast cells in the non- $\overrightarrow{\vec{B}}$ fibrous parts of the marrow in the two osteitis $\frac{3}{3}$

\begin{tabular}{|c|c|c|c|c|c|}
\hline \multirow{2}{*}{ Group } & \multirow{2}{*}{ Number } & \multicolumn{3}{|c|}{ Mast Cells per $\mathrm{mm}^{2}$ Marrow } & \multirow{2}{*}{$\begin{array}{l}\text { Comparisons with Controls } \\
\text { (Mann-Whitney Test) }\end{array}$} \\
\hline & & Range & Mean & Median & \\
\hline $\begin{array}{l}\text { Control } \\
\text { Renal (necropsies) } \\
\text { Renal (biopsies) } \\
\text { All renal }\end{array}$ & $\begin{array}{l}61 \\
23 \\
22 \\
45\end{array}$ & $\begin{array}{r}0-33.76 \\
0.96-29.51 \\
1 \cdot 18-55.63 \\
0.96-55.63\end{array}$ & $\begin{array}{r}3.93 \\
8 \cdot 65 \\
19 \cdot 09 \\
13.75\end{array}$ & $\begin{array}{r}1.95 \\
7.62 \\
14 \cdot 87 \\
9 \cdot 55\end{array}$ & $\begin{array}{l}\bar{P}<0.001 \\
P<0.001 \\
P<0.001\end{array}$ \\
\hline
\end{tabular}

Table II Marrow mast cell values in 61 controls and 45 patients with chronic renal failure

\begin{tabular}{|c|c|c|c|c|c|c|}
\hline \multirow[t]{3}{*}{ Group } & \multicolumn{3}{|c|}{$\begin{array}{l}\text { Osteitis Fibrosa Grade } \\
0-2\end{array}$} & \multicolumn{3}{|c|}{$\begin{array}{l}\text { Osteitis Fibrosa Grade } \\
2 \cdot 5-5\end{array}$} \\
\hline & \multirow{2}{*}{ Number } & \multicolumn{2}{|c|}{ Mast Cells per $\mathrm{mm}^{2}$} & \multirow{2}{*}{ Number } & \multicolumn{2}{|c|}{ Mast Cells per $\mathrm{mm}^{2}$} \\
\hline & & Mean & Median & & Mean & Median \\
\hline $\begin{array}{l}\text { Biopsies } \\
\text { Necropsies } \\
\text { Combined }\end{array}$ & $\begin{array}{l}10 \\
16 \\
26\end{array}$ & $\begin{array}{r}12 \cdot 84 \\
8 \cdot 02 \\
9 \cdot 88\end{array}$ & $\begin{array}{l}7 \cdot 68 \\
6 \cdot 84 \\
6 \cdot 83\end{array}$ & $\begin{array}{r}12 \\
7 \\
19\end{array}$ & $\begin{array}{l}24 \cdot 30^{2} \\
10 \cdot 08^{2} \\
19 \cdot 06^{1}\end{array}$ & $\begin{array}{r}21 \cdot 18 \\
7 \cdot 98 \\
15 \cdot 51\end{array}$ \\
\hline
\end{tabular}

Table III Relationship between number of marrow mast cells and severity of osteitis fibrosa

${ }^{1}$ Significant difference between groups with grade $\mathbf{0 - 2}$ and $2.5-5$ osteitis fibrosa, $P<0.05$

'No significant difference between groups grade 0-2 and 2.5-5 osteitis fibrosa, $P>0 \cdot 10$ 
fibrosa groups in the 24 cases in which differential counts were made. Thus the groups osteitis fibrosa grades $0-2$ and 2.5-5 had respective means of 11.74 and 11.47 mast cells per $\mathrm{mm}^{2}$ of mixed fatty and cellular marrow.

Plotting the numbers of osteoclasts per square millimstre of bone against the corresponding numbers of total marrow mast cells or non-fibrous marrow mast cells revealed a random scatter of points with no suggestion of any significant relationship. The number of marrow mast cells was not related to the amount of woven bone formation.

Number of mast cells and state of bone mineralization The presence of osteomalacia was not related to the number of marrow mast cells. The values for the range, mean, and median for 10 cases with osteomalacia were $0.96-29 \cdot 51,12 \cdot 76$, and 10.01 mast cells per $\mathrm{mm}^{2}$, respectively. The corresponding values for the 35 cases without osteomalacia were, respectively, $1 \cdot 18-55.63,14.04$, and 9.55 mast cells per $\mathrm{mm}^{2}$.

Attempts to relate the amounts of osteoid, expressed as a percentage of a measured area of bone and marrow, to the numbers of marrow mast cells were unsuccessful in osteomalacic and nonosteomalacic samples. Similarly, there was no significant relationship between the percentage mineralization of cancellous bone and the number of marrow mast cells.

\section{Discussion}

The present observations indicate that mast cells are to be found in histological sections of iliac bone marrow in the majority of individuals. We have regarded as tissue mast cells all those mononucleated cells in the marrow with intracytoplasmic metachromatic granules. It seems to be generally accepted that the solubility characteristics of basophilic leucocytes make them unrecognizable in tissue when an aqueous or alcoholic fixative has been used (Johnstone, 1954), whereas human mast cell granules are relatively insoluble in watery fixatives (Johnstone, 1954; Kramer and Windrum, 1955; Sagher and Even-Paz, 1967). The solubility of mast cell granules varies between different animal species. Mouse, rat, and human mast cell granules are well preserved after formalin fixation but non-aqueous fixatives are necessary in the case of lower vertebrates and in the guinea-pig and dog (Benditt and Dunn, 1963). The shape of mast cells was noted to vary, most being ovoid or rounded but some were elongated around the surface of fat cells or were distinctly spindle shaped. Granules were frequently sufficiently dense and numerous to obscure nuclear detail. Individual mast cells were scattered throughout the marrow with a tendency to lie alongside cancellous trabeculae, around blood vessels or arranged in groups with wide intervening areas devoid of mast cells. This type of distribution inevitably limits the precise value of mast cell counts made in small areas which may not necessarily be representative. Any changes observed in serial bone biopsies from individual patients must therefore be interpreted with caution. In the present study we are concerned mainly with a comparison of two different groups of subjects so that any differences encountered between the groups as a whole may be regarded as meaningful.

In the control necropsy series comprising 61 individuals, the distribution of values for the numbers of marrow mast cells was not a normal one and we have therefore not quoted the mean and standard error. The control values were range $0-33.76$, arithmetic mean 3.93 , and median 1.95 mast cells per $\mathrm{mm}^{2}$ marrow. We have no explanation for the fact that $10 \%$ of individuals had mast cell values in excess of 10 per $\mathrm{mm}^{2}$ marrow, and these values were apparently unrelated to the mode of death.

In the group of 45 patients with chronic renal failure taken as a whole there were significantly more marrow mast cells (arithmetic mean 13.75 and median 9.55 per $\mathrm{mm}^{2}$ ) than in the control group $(P<0.001)$. Again the distribution of values was not a normal one and comparisons between the various groups throughout this study have been made using the appropriate Mann-Whitney test (Snedecor and Cochran, 1971). Within the renal group there was a significantly higher range of mast cell values for those samples obtained by iliac crest biopsy as compared to those obtained at necropsy. This raises the possibility that better preservation of mast cells and hence easier recognition result from rapid fixation of the biopsy samples, whereas in the case of the necropsy specimens there would inevitably be a delay between death and the subsequent fixation of tissues at the time of the necropsy. We cannot exclude this possibility, but it does not alter the significance of the increased numbers of marrow mast cells observed in renal disease since even in the necropsy specimens significantly more mast cells occurred in the renal failure patients than in the controls $(P<0.001)$. Furthermore, we have observed in serial bone biopsies from patients treated by renal transplantation, where conditions of fixation of specimens were identical, a return of marrow mast cells to the control range.

The difference between renal biopsy and necropsy cases may also be attributable in part to the fact that there were more severe examples of osteitis fibrosa in the biopsy series with more marrow fibrous tissue which included frequent mast cells. In the bone of patients with chronic renal failure there was com- 
monly evidence of osteitis fibrosa due to secondary hyperparathyroidism. Mast cells were often conspicuous within the zones of marrow fibrosis in such cases, and we were able to demonstrate a significant relationship between the total number of marrow mast cells and the amount of marrow fibrosis. We have also observed mast cells in the fibrous tissue of organizing iliac bone biopsy sites, and it is well recognized that mast cells may occur in many sites of repair where there is connective tissue proliferation such as fracture callus (Selye, 1965; Lindholm et al, 1969; Lindholm and Lindholm, 1970). From our observations we are not certain that all the cells counted as mast cells in the marrow fibrous tissue are true mast cells. Some of the cells may have been fibroblasts which had taken up metachromatic granules from adjacent disrupted mast cells (Higginbotham et al, 1956).

That the mast cells in marrow fibrous tissue did not alone account for the increased numbers of marrow mast cells in renal failure was shown by the finding of increased numbers of mast cells in the mixed fatty and haemopoietic marrow of these patients. This suggests that there is some other factor in renal failure which is responsible, at least in part, for the increase in marrow mast cells. This concept is supported by the report that mast cells are increased in tissues other than the bone marrow in chronic renal failure, such as the spleen (Neiman et al, 1972). These authors put forward the hypothesis that hyperparathyroidism, which is almost invariably present in chronic renal failure (Gilmour, 1947; Ellis and Peart, 1973), may account for tissue mast cell proliferation since there is evidence to suggest in experimental animals that parathormone stimulates the accumulation of mast cells in bone (Rockoff and Armstrong, 1970; Rasmussen, 1972). This could be the explanation for the excess of mast cells in the fibrous tissue component of the osteitis fibrosa and in the remaining nonfibrous marrow. To test this hypothesis we have tried to relate the severity of the osteitis fibrosa, representing the degree of hyperparathyroidism, to the number of mast cells both in the marrow as a whole and in the non-fibrous marrow. The results showed a tendency towards greater numbers of mast cells in those bone samples with the more severe grades of osteitis fibrosa. When the combined renal biopsy and necropsy samples were considered, there was a low order of significant difference $(P<0.05)$ between the number of total marrow mast cells in the group with osteitis fibrosa grades 0 to 2 and that with grades 2.5 to 5 . This difference was almost certainly associated with the greater amounts of fibrous tissue with mast cells in the marrow of the samples with more severe grades of osteitis fibrosa.
Thus there were similar numbers of mast cells in the non-fibrous parts of the marrow in the two osteitis fibrosa groupings in 24 individuals where differential $\vec{F}$ counts of mast cells in fibrous and non-fibrous $\stackrel{\rho}{+}$ marrow were made. As another measure of hyperparathyroidism (Ellis and Peart, 1973) we considered $\frac{\bar{\sigma}}{\bar{D}}$ the number of osteoclasts per square millimetre of $\frac{\sigma}{\sigma}$ bone in relation to the number of mast cells but $\varnothing$ there was no significant relationship. We therefore क have no definite evidence to indicate a relationship $\overrightarrow{0}$ between the degree of hyperparathyroidism and the number of marrow mast cells. Indeed, what evidence $\vec{\omega}$ exists suggests that there may not be any direct relationship. Preliminary observations we have made $\frac{8}{0}$ in serial bone biopsies from patients with chronic renal failure before and after treatment with calcium $\vec{N}$ carbonate and aluminium hydroxide or by para- 0

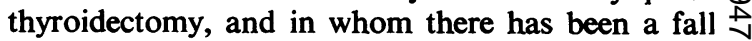
in serum parathormone and a reduction in the $ᄋ$ severity of osteitis fibrosa histologically, have shown no corresponding reduction in the excess of mast cells. This is against the hypothesis that there is a relationship between hyperparathyroidism and numbers of marrow mast cells. A further difficulty in any attempt to relate the number of marrow mast cells to the degree of osteitis fibrosa is the duration of the changes. The number of mast cells may be a function on of the stage of development of the osteitis fibros and the age of the marrow fibrous tissue componen By analogy with the changing numbers of mast cells in the processes of organization and repair elsewhere, such as in the healing of a wound (Wichmann, 1955), one would expect most mast cells to be present during the active phase of marrow fibrosis and subsequently to be reduced.

Johnstone (1954) observed that the presence and number of mast cells in the marrow were not related to the iron content of the marrow or to the degree of erythropoiesis and that anaemia was the only factor common to all the cases in which mast cells were prominent. The majority of our patients with chronic renal failure had some degree of anaemia but there was no relationship between the number of marrow mast cells and the haemoglobin concentration of the blood within the group of renal patients.

There are no data in the literature strictly comparable with that presented here but Rebel et al (1974) have reported marrow mast cell counts in 21 patients with renal failure treated by haemodialysis in the range 0 to 60.0 per $\mathrm{mm}^{2}$, which is within the range 6 we have found in renal failure. These authors do not report any control values however. In 11 other patients with, for example, osteomalacia or osteoporosis, the range was 0.1 to 23.0 mast cells per $\mathrm{mm}^{2}$ of marrow. Highest marrow mast cell values were 
observed in patients with osteomalacia whether this was the result of renal failure or other causes, and the authors suggested that osteomalacia alone is sufficient to bring about an increase in the number of marrow mast cells. We were unable to confirm this relationship between osteomalacia and numbers of marrow mast cells in our patients with chronic renal failure, and there was no significant relationship between numbers of mast cells and the amount of osteoid per cent of the measured bone area, or the percentage mineralization of cancellous bone. The nature of the bone changes in chronic azotaemia depends upon the severity and duration of the renal disease. Hyperparathyroidism occurs at an early stage, so that in an unselected series of patients with chronic renal failure one can expect about $90 \%$ to show histological evidence of osteitis fibrosa whereas osteomalacia, which develops later, occurs in only about one-third (Ellis and Peart, 1973). In any unselected series of patients with chronic renal failure the duration and severity of osteomalacia will vary from case to case. The rate of formation of osteoid also seems to vary so that some patients show relatively little increase in osteoid in serial biopsies whereas in others it is more rapid, and large amounts of osteoid accumulate and make a significant contribution to osteosclerosis. If there is a relationship between the numbers of marrow mast cells and osteomalacia then it might be that mast cells are associated with some particular stage in the development or persistence of osteomalacia. The incidence of osteomalacia in haemodialysed patients increases with time on dialysis (Ellis and Peart, 1971a) so that in a series of dialysed patients, such as that reported by Rebel et al (1974), some patients would have recent and active development of osteomalacia. If this early stage of osteomalacia is associated with increased marrow mast cells, then this could explain the discrepancy between the results of these authors in haemodialysed patients and in our own non-dialysed patients. We are currently accumulating data on patients treated by long-term haemodialysis who have developed osteomalacia and we hope to be able to elucidate this aspect of the problem in the future. Increased numbers of mast cells alongside bone cancellous trabeculae have been described in rats on a low-calcium and vitamin $\mathbf{D}$ deficient diet (Shipley et al, 1922; Urist and McLean, 1957; Cass et al, 1958) and the mast cells were reduced in number after treatment with vitamin $D$.

Increased numbers of marrow mast cells appear to be associated with experimental resorption and remodelling of bone whatever the cause (Gillman, 1958; Lalich, Groupner, and Jolin, 1965; Severson, 1969), and it is possible that the presence of excess mast cells in azotaemia is a secondary manifestation of bone resorption and formation. The precise relationship between mast cells and bone resorption and formation does not appear to have been resolved. Local effects of heparin may be responsible since it is known that the administration of heparin and similar but synthetic polysaccharides to experimental animals is associated with bone resorption and impaired ossification (Gillman and Naidoo, 1957; Ellis, 1965). Osteoporosis has also been reported following the long-term administration of heparin to patients (Griffith et al, 1965; Jaffe and Willis, 1965; Schuster et al, 1969). The mechanisms involved are unknown although it has been shown that heparin stimulates collagenase activity (Asher and Nichols, 1965; Sakamoto et al, 1973) and that heparin is capable of releasing lysozymal enzymes which might be involved in bone resorption (Sledge and Blackburn, 1968). It has been shown (Ellis and Peart, 1970) that heparin increases the resorption of diaphyseal bone in cultured mouse limb bones, suggesting that there is a direct effect of heparin on bone. This effect occurred, however, only with higher concentrations of heparin than are reached in the blood and tissues of intact animals even after prolonged administration. For the in vivo changes to be the result of a direct toxic effect on bone there would have to be a selective accumulation of heparin in bone tissues. The excess marrow mast cells in the present cases are, of course, already near to the bone, and there might be localized zones of high heparin concentration. Others have suggested that the bone resorptive effect of heparin is an indirect one and mediated through hyperparathyroidism resulting from the hypocalcaemia following the binding of serum calcium ions by heparin (Hahnemann, 1965). This hypothesis is not borne out by the observations that calcium heparin is equally effective as sodium heparin in inducing osteoporosis (Ellis, 1965) and that parathyroidectomy does not prevent development of heparinoid osteopathy (Ellis and Peart, 1971b). There is also evidence from tissue culture experiments to suggest that heparin may enhance bone resorption by acting as a parathormone cofactor (Goldhaber, 1965).

In discussing the possible local effects on bone of mast cells, one has to consider the relatively rare condition of systemic mastocytosis where there is infiltration of the skin and other tissue by mast cells (Sagher and Even-Paz, 1967). Bone sections have bsen reported as showing resorption of trabeculae related to collections of mast cells, deposition of fibrillary lamellar bone, and trabecular thickening, marrow fibrosis, and osteosclerosis (Stark et al, 1956; Jensen and Lasser, 1958; Havard and Scott, 1959; Lerner and Lerner, 1960). In azotaemic renal osteodystrophy osteosclerosis may occur when the 
amounts of osteoid and mineralized woven bone formed exceed the loss of mineralized lamellar and woven bone due to excess osteoclasis (Ellisand Peart, 1973). Woven bone is particularly rich in sulphated polysaccharides but we could not find any definite relationship between the numbers of marrow mast cells and the total amount of bone or the amount of woven bone in the present cases.

In conclusion, our results indicate that there is an increase in the number of mast cells in the marrow of patients with chronic renal failure. Although there are commonly numerous mast cells within the fibrous parts of the marrow forming part of the osteitis fibrosa reaction, we have been unable to explain the increased mast cells in renal failure solely on the basis of hyperparathyroidism. In addition, there does not appear to be any clear relationship in the present cases between the number of marrow mast cells and the presence or severity of a bone mineralization defect.

We wish to thank Dr. D. R. Appleton of the Department of Medical Statistics for statistical advice. It is again a pleasure to acknowledge the help of our clinical colleagues in the Departments of Medicine and Surgery who provided the bone biopsies. One of us (KMP.) is in receipt of an MRC grant (no. G973/693/C).

\section{References}

Asher, J. D. and Nichols, G., Jr. (1965). Heparin stimulation of bone collagenase activity. Fed. Proc., 24, (Abstract), 211.

Benditt, E. P.: Dunn, T. B. (1963). Mast cells and basophils; Round Table Discussion. Ann. N.Y. Acad. Sci., 103, 452-453.

Cass, R., Marshall, P. B., and Riley, J. F. (1958). 5-Hydroxytryptamine and histamine in mast cells of the mouse and rat. J. Physiol. (Lond.), 141, 510-519.

Ellis, H. A. (1965). Effects of the long-term administration to animals of dextran sulphate. J. Path. Bact., 89, 437-460.

Ellis, H. A. (1973). Bone disease in end-stage renal failure (Letter). Brit. med. J., 3, 232-233.

Ellis, H. A. and Peart, K. M. (1970). The effects of heparin and dextran sulphate on cultured mouse limb bones. Brit. J. exp. Path., 51, 43-52.

Ellis, H. A. and Peart, K. M. (1971a). Renal osteodystrophy with particular reference to the effects of chronic intermittent haemodialysis (Abstract). Nephron, 8, 402.

Ellis, H. A. and Peart, K. M. (1971b). Dextran sulphate osteopathy in parathyroidectomised rats. Brit. J. exp. Path., 52, 684-695.

Ellis, H. A. and Peart, K. M. (1972). Quantitative observations on mineralized and non-mineralized bone in the iliac crest. J. clin. Path., 25, 277-286.

Ellis, H. A. and Peart, K. M. (1973). Azotaemic renal osteodystrophy: a quantitative study on iliac bone. J. clin. Path., 26, 83-101.

Fadem, R.S. (1951). Tissue mast cells in human bone marrow. Blood, 6, 614-630.

Gillman, T. (1958). Mast cell increases after calciferol intoxi- cation and in experimental odoratism. Acta haemat. (Basel), 19, 179-186.

Gillman, T. and Naidoo, S. S. (1957). In vitro effects of heparin and calcium ions on lipaemic serum. Nature (Lond.), 179, 904-905.

Gilmour, J. R. (1947). The Parathyroid Glands and Skeleton in Reral Discase. Cumberlege, Oxford University Press, London.

Goldhaber, P. (1965). Heparin enhancement of factors stimulating bone resorption in tissue culture. Science, 147, 407-408.

Griffith, G. C., Nichols, G., Jr., Asher, J. D., and Flanagan, B. (1965). Heparin osteoporosis. J. Amer. med. Ass., 193, 91-94.

Hahnemann, S. (1965). Heparin and osteoporosis (Letter) Lancet, 2, 855-856.

Havard, C. W. H. and Scott, R. B. (1959). Urticaria pigmentosa with visceral and skeletal lesions. Quart. J. Med., ¿8, 459-470.

Higginbotham, R. D., Dougherty, T. F., and Jee, W. S. S. $\vec{v}$ (1956). Fate of shed mast cell granules. Proc. Soc. exp. ? Biol. (N.Y.), 92, 256-261.

Jaffe, M. D. and Willis, P. W., III. (1965). Multiple fractures associated with long-term sodium heparin therapy.J. Amer. med. Ass., 193, 158-160.

Jensen, W. N. and Lasser, E. C. (1958). Urticaria pigmentosa associated with widespread sclerosis of the spongiosa of bone. Radiology, 71, 826-832.

Johnstone, J. M. (1954). The appearance and significance of tissue mast cells in human bone marrow. J. clin. Path. 7, 275-280.

Kramer, H. and Windrum, G. M. (1955). The metachromatic $\vec{c}$ staining reaction. J. Histochem. Cytochem., 3, 227-237.

Lalich, J. J., Groupner, K., and Jolin, J. (1965). The influene of copper and molybdate salts on the production of boz deformities in rats. Lab. Invest., 14, 1482-1493.

Lerner, M. R. and Lerner, A. B. (1960). Urticaria pigmentosa with systemic lesions and otosclerosis. Arch. Derm., 81, 203-204.

Lindholm, R. V. and Lindholm, T. S. (1970). Mast cells in endosteal and periosteal bone repair. Acta orthop. scand., $\overrightarrow{\vec{F}}$ 41, 129-133.

Lindholm, R., Lindholm, S., Liukko, P., Paasimäki, J., Isokääntä, S., Rossi, R., Autio, E., and Tamminen, (1969). The mast cell as a component of callus in healing fractures. J. Bone Jt Surg., 51b, 148-155.

Neiman, R. S., Bischel, M. D., and Lukes, R. J. (1972). Uraemia and mast-cell proliferation (Letter). Lancet, 1, 959.

Rasmussen, P. (1972). An experimental study of mast cells in the rat metaphysis. Calcif. Tiss. Res., 9, 325-330.

Rebel, A., Riberi, P., Bregeon, P., and Malkani, K. (1974). Mastocytes et remaniements du tissu osseux. Path. et Biol., 22, 213-220.

Rockoff, S. D. and Armstrong, J. D., Jr., (1970). Parathyroid I hormone as a stimulus to mast cell accumulation in bone. Calcif. Tiss. Res., 5, 49-55.

Sagher, F. and Even-Paz, Z. (1967). Mastocytosis and the $\mathcal{O}$ Mast Cell. Karger, Basle and Year Book Medical N Publishers, Chicago.

Sakamoto, S., Goldhaber, P., and Glimcher, M. J. (1973). స Mouse bone collagenase: the effect of heparin on the $\sigma$ amount of enzyme released in tissue culture and on the activity of the enzyme. Calcif. Tiss. Res., 12, 247-258.

Schuster, J., Meier-Ruge, W., and Egli, F. (1969). Zur Pathologie der Osteopathie nach Heparinbehandlung. Dtsch. med. Wschr., 94, 2334-2338.

Selye, H. (1965). The Mast Cells. Butterworths, Washington D.C., and London.

Severson, A. R. (1969). Mast cells in areas of experimental 
bone resorption and remodelling. Brit. J. exp. Path., 50, 17-21.

Shipley, P. G., Park, E. A., McCollum, E. V., and Simmonds, N. (1922). Is there more than one kind of rickets? Amer.J. Dis. Child., 23, 91-106.

Sledge, C. B. and Blackburn, W. W. (1968). Heparin, dextran and dextran sulfate: effect on lysosomes from embryonic cartilage. Calcif. Tiss. Res., 2, Suppl. (Abstract), 65-65a.

Snedecor, G. W. and Cochran, W. G. (1971). Statistical Methods, 6th edition. p. 130. Iowa State University Press, Ames, Iowa.
Stark, E., Van Buskirk, F. W., and Daly, J. F. (1956). Radiologic and pathologic bone changes associated with urticaria pigmentosa. Report of a case. Arch. Path., 62, 143-148.

Urist, M. R. and McLean, F. C. (1957). Accumulation of mast cells in endosteum of bones of calcium-deficient rats. Arch. Path., 63, 239-251.

Wichmann, B. E. (1955). The mast cell count during the process of wound healing: an experimental investigation on rats. Acta path. microbiol. scand., suppl. 108, 1-35. 